\title{
Increasing hepatitis virus screening uptake at worksites in Japan using nudge theory and full subsidies
}

\author{
Jun Fukuyoshi ${ }^{1}$, Masaaki Korenaga ${ }^{2 *}$, Yui Yoshii ${ }^{3}$, Lek Hong ${ }^{4}$, Soichiro Kashihara ${ }^{5}$, Byron Sigel ${ }^{6}$ and
} Toru Takebayashi ${ }^{1}$

\begin{abstract}
Background: Despite the importance of hepatitis screening for decreasing liver cancer mortality, screening rates remain low in Japan. Previous studies show that full subsidies increase screening uptake, but full subsidies are costly and difficult to implement in low-resource settings. Alternatively, applying nudge theory to the message design could increase screening at lower costs. This study examined the effects of both methods in increasing hepatitis virus screening rates at worksites.

Methods: 1496 employees from a Japanese transportation company received client reminders for an optional hepatitis virus screening before their general health checkups. Groups A and B received a client reminder designed based on the principles of "Easy" and "Attractive," while the control group received a client reminder not developed using nudge theory. Additionally, hepatitis virus screening was offered to the control group and group A for a copayment of JPY 612, but was fully subsidized for group B. The hepatitis virus screening rates among the groups were compared using a Chi-square test with Bonferroni correction, and the risk ratios of group A and group B to the control group were also calculated. To adjust for unobservable heterogeneity per cluster, the regression analysis was performed using generalized linear mixed models.
\end{abstract}

Results: The screening rate was $21.2 \%, 37.1 \%$, and $86.3 \%$ for the control group, group A, and group B, respectively. And the risk ratio for group A was 1.75 (95\% confidence interval [Cl] 1.45-2.12) and that of group B was 4.08 (95\% Cl 3.44-4.83). The parameters of group $A$ and group $B$ also were significant when estimated using generalized linear mixed models. However, the cost-effectiveness (incremental cost-effectiveness ratio (ICER)) of the nudgebased reminder with the full subsidies was lower than that of only the nudge-based reminder.

Conclusions: While fully subsidized screening led to the highest hepatitis screening rates, modifying client reminders using nudge theory significantly increased hepatitis screening uptake at lower costs per person.

Keywords: Nudge, Behavioral science, cancer screening, client reminder, Hepatitis virus screening, Hepatitis at worksites, Message simplification

\footnotetext{
* Correspondence: dmkorenaga@hospk.ncgm.go.jp

${ }^{2}$ Hepatitis Information Center, The Research Center for Hepatitis and

Immunology, National Center for Global Health and Medicine, Ichikawa,

Chiba 272-8516, Japan

Full list of author information is available at the end of the article
}

(c) The Author(s). 2021 Open Access This article is licensed under a Creative Commons Attribution 4.0 International License, which permits use, sharing, adaptation, distribution and reproduction in any medium or format, as long as you give appropriate credit to the original author(s) and the source, provide a link to the Creative Commons licence, and indicate if changes were made. The images or other third party material in this article are included in the article's Creative Commons licence, unless indicated otherwise in a credit line to the material. If material is not included in the article's Creative Commons licence and your intended use is not permitted by statutory regulation or exceeds the permitted use, you will need to obtain permission directly from the copyright holder. To view a copy of this licence, visit http://creativecommons.org/licenses/by/4.0/. The Creative Commons Public Domain Dedication waiver (http://creativecommons.org/publicdomain/zero/1.0/) applies to the data made available in this article, unless otherwise stated in a credit line to the data. 


\section{Introduction}

Liver cancer is one of the leading causes of cancer deaths worldwide [1]. In Japan, an estimated 29,000 people died of liver cancer in 2017 [2]. Furthermore, approximately 70\% of liver cancer cases in Japan develop from an infection caused by the hepatitis $\mathrm{B}$ virus (HBV) or hepatitis $\mathrm{C}$ virus (HCV) [3]. These patients, especially those who are infected with $\mathrm{HCV}$, can be cured with minimal adverse effects using direct-acting antivirals (DAAs) [4]. Thus, the early detection of the hepatitis virus infection by screening is a major public health goal.

To promote hepatitis screening, the Japanese government enacted the Basic Act on Hepatitis Countermeasures in 2009, encouraging municipalities to provide hepatitis virus screening for citizens over 40 years of age [5]. As a result, hepatitis virus screening rates at the municipal level increased. However, hepatitis virus screening rates at worksites remain low in Japan. A previous study surveying 2420 employees showed that only $13.8 \%$ had undergone hepatitis screening [6].

Previous studies suggest that providing cancer screenings free of charge could increase screening rates [7]. For example, in Japan, eliminating cost significantly increased screening rates for cervical cancer screening [8]. However, even if free screening is effective, this can add substantial costs to providers as well as employers. Alternatively, applications of nudge theory tend to be low-cost solutions [9], and substantial evidence demonstrates its effectiveness in the realm of cancer screenings [10-12]. Nudge theory, as defined by Thaler and Sunstein, "is any aspect of the choice architecture that alters people's behavior in a predictable way without forbidding any options or significantly changing their economic incentives" [13]. To illustrate, in Hachioji city, Japan, the city office developed client reminders based on nudge theory and sent to non-takers of colorectal cancer (CRC) screening. These reminders focused on (i) readability and (ii) the low co-payment for screening due to subsidies [14]. This nudge-theory-based reminder led to a CRC uptake of $26.8 \%$, exceeding initial expectations of $19 \%$. Nudge theory could change behavior by modifying the perception of the screening without offering significant financial incentives. Therefore, it is important to compare not only the effectiveness but also the cost-effectiveness of these interventions in promoting hepatitis screening.

Currently, few studies aim to promote the hepatitis virus screening rates at worksites. For many small- to medium-sized companies in Japan, the Japan Health Insurance Association (JHIA) covers the healthcare costs for workers. As of 2015, 17 million workers over the age of 40 were enrolled [15]. This study examines the effects of (i) making screenings free of charge and (ii) applying nudge theory to the design of client reminders on hepatitis virus screening among members of JHIA. Given the large number of premium holders under JHIA, these results could significantly contribute to a reduction in patients with liver cancer in Japan.

\section{Methods \\ Setting}

As a member of JHIA, the transportation company provided general health checkups to 12,450 employees as mandated by the Industrial Safety and Health Act [16]. Hepatitis virus screening was offered as an optional test for JPY 612 (US\$6) during these general checkups. From 2015 to 2016, a trial program was conducted and designed by the transportation company to increase the uptake of hepatitis virus screening among its employees, who were mostly truck drivers.

\section{Procedure}

Participants were included if they (i) applied and attended the general health checkups conducted in July 2015 and January 2016 and (ii) were 35-74 years old. 1496 employees met the inclusion criteria.

The company designed and executed a clusterrandomized trial, in which the thirteen tracking stations located in urban cities were randomly assigned to control group, group A, or group B (Fig. 1). The employees received different types of client reminders depending on the tracking stations they worked at. Client reminders were sent a few weeks before the general health checkups. Information on the homogeneity among the groups is provided in the results.

\section{Intervention}

The control group $(n=534)$ received the client reminder created without applying nudge theory (Fig. 2a). While this reminder included detailed information, including the risks and benefits of undertaking hepatitis virus screening, the reminder was wordy (342 words) and difficult to read.

Group A $(n=655)$ received the client reminder designed using nudge-theory (Fig. 2b), specifically the "EAST" framework [17] created by the UK's Behavioural Insights Team (BIT). According to BIT, the four principles for effective behavior change are as follows: easy, attractive, social, and timely. Specifically, our study focused on the principles of easy and attractive. To simplify the message, as recommended by the BIT executive report, information on the risks of hepatitis and the benefits of hepatitis virus screening was removed, reducing the word count to 152 words [17]. Also, the discounted cost was emphasized by striking out the original cost of screening (JPY 2040) and using capital letters for the new cost (JPY 612).

\section{Hepatitis virus screening free of charge}

Although the hepatitis virus screening cost of the control group and group A was JPY 612, group B $(n=307)$ was offered the hepatitis virus screening free of charge (shown in Fig. 3). 


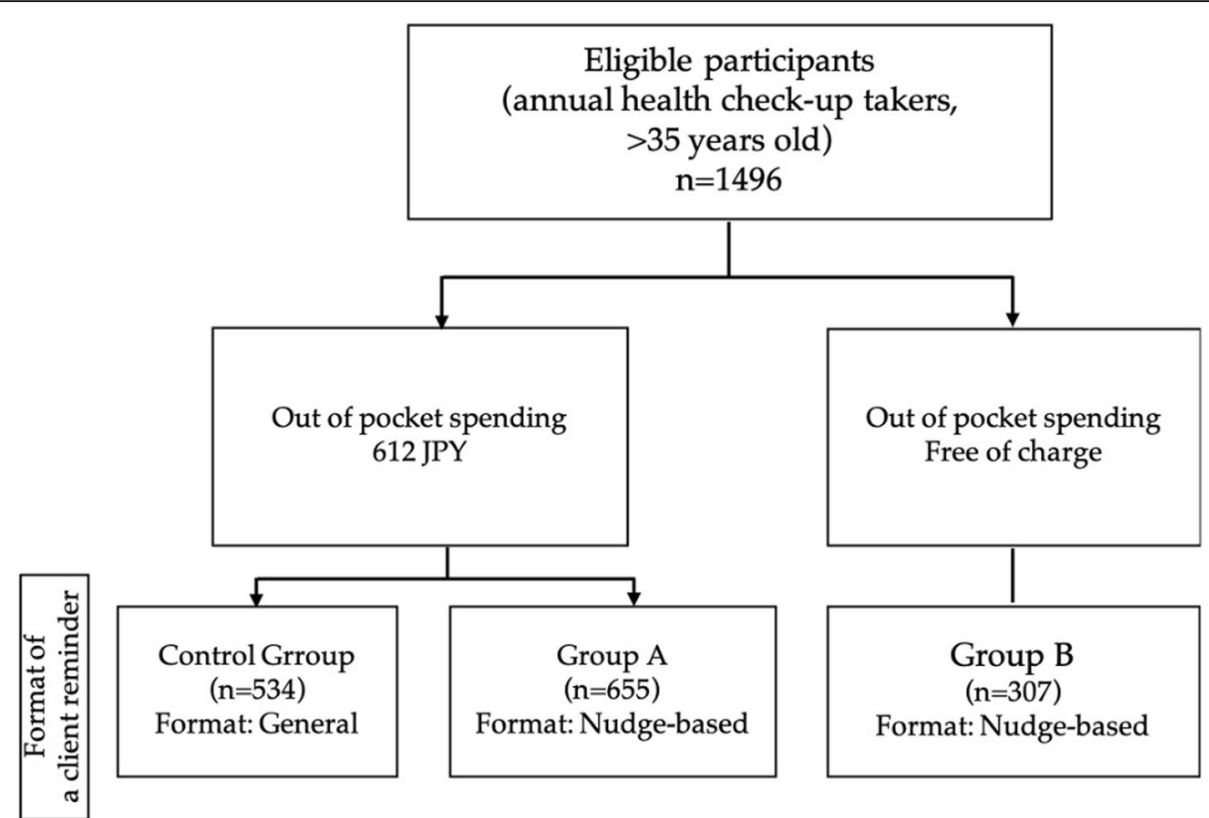

Fig. 1 Flow diagram of the trial process

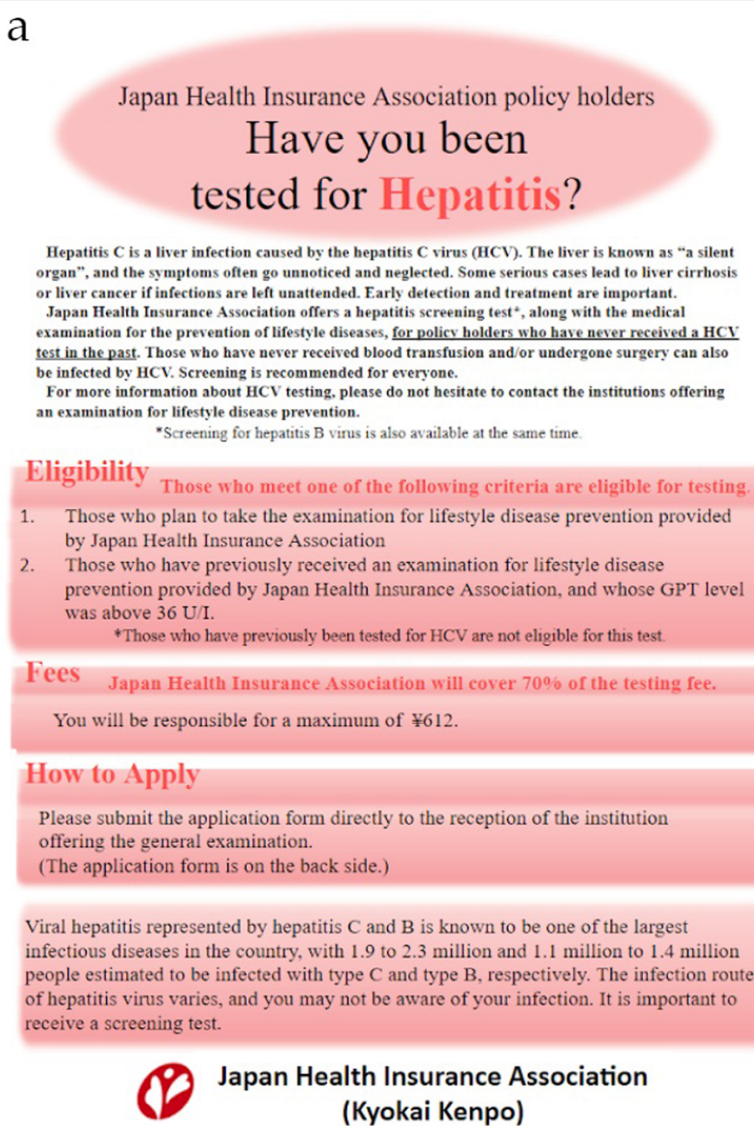

Hepatitis $\mathrm{C}$ is a liver infection caused by the hepatitis $\mathrm{C}$ virus $(\mathrm{HCV})$. The liver is known as "a silent organ", and the symptoms often go unnoticed and neglected. Some serious cases lead to liver cirrhosis or liver cancer if infections are left unattended. Early detection and treatment are important. Japan Health Insurance Association offers a hepatitis screening test ${ }^{*}$, along with the medical examination for the prevention of lifestyle diseases, for policy holders who have never received a HCV
test in the past. Those who have never received blood transfusion and/or undergone surgery can also be infected by HCV. Screening is recommended for everyone.

For more information about $\mathrm{HCV}$ testing, please do not hesitate to contact the institutions offering

"Screening for hepatitis B virus is also available at the same time

Eligibility

Those who meet one of the following criteria are eligible for testing.

1. Those who plan to take the examination for lifestyle disease prevention provided by Japan Health Insurance Association

2. Those who have previously received an examination for lifestyle disease prevention provided by Japan Health Insurance Association, and whose GPT level was above $36 \mathrm{U} / \mathrm{I}$.

Those who have previously been tested for $\mathrm{HCV}$ are not eligible for this test

Fees Japan Health Insurance Association will cover $70 \%$ of the testing fee. You will be responsible for a maximum of $¥ 612$.

Japan Health Insurance Association (Kyokai Kenpo)

b To Japan Health Insurance Association policy holders

\section{Notice \\ for Hepatitis Screening}

At the Japan Health Insurance Association health check-up, a hepatitis screening test is available at the same time as the health examination for lifestyle disease prevention. The test normally costs $¥ 2040$,

but it is currently available at $¥ 612$.

Please take this opportunity to be tested.

(※) Those who have previously been tested for hepatitis $\mathrm{C}$ virus are not eligible for this test.

\section{Hepatitis Testing Outline}

Testing Fee:

$¥ 2040$

$¥ 612$

How to apply: Please fill out the back side of this form.

Testing method

A blood sample will be collected at the time of blood

sampling at the general medical examination.

No additional testing is necessary.

If you wish to be tested, please fill out the back side of this form and submit it to the reception desk at the time of the general medical examination.

Japan Health Insurance Association (Kyokai Kenpo)

Fig. 2 Client reminders (translated). a Control group client reminder. b Group A client reminder 
To Japan Health Insurance Association policy holders

\section{Notice for Hepatitis Screening}

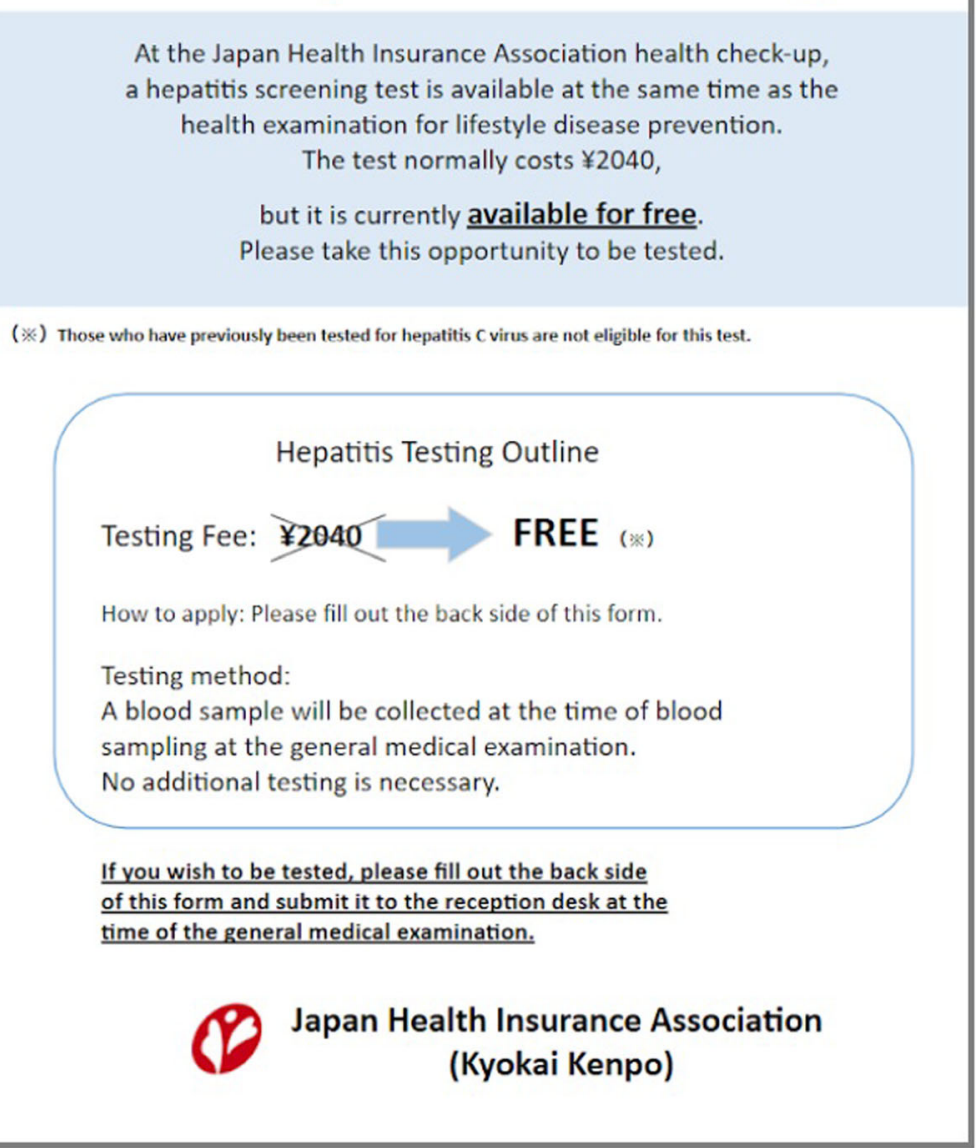

Fig. 3 The client reminder for group B

For group B, the reminder was written in the same format as that of group A, except that the hepatitis virus screening was indicated as free of charge (Fig. 3).

\section{Data collection and measures Primary outcome}

The primary outcome was hepatitis virus screening rate. The healthcare provider checked the number of employees who had undergone the hepatitis virus screening using a standard record-keeping process.

\section{Statistical analysis}

We described the sex and age distributions of the participants, and we performed a chi-squared test to measure any differences among intervention groups. We quantified the difference in hepatitis virus screening among groups using a chi-squared test with a Bonferroni correction. These analyses were performed using Python 3.6 (The Python Software Foundation, Delaware, USA). Also, we calculated risk ratios. In addition, a regression analysis was performed using generalized linear mixed models to see if significant differences exist even after adjusting for unobservable heterogeneity per cluster. Calculation of risk ratios and the regression analysis were performed using R 4.0.2 (R Foundation for Statistical Computing, Vienna, Austria).

\section{Economic analysis}

Cost-effectiveness was calculated using the incremental cost-effectiveness ratio (ICER), expressed in terms of JPY per one additional person screened. 


$$
\mathrm{ICER}=\frac{\text { Difference in costs between the control group and the intervention groups (group A or group B) }}{\text { Difference in number of screening takers between the control group and the intervention groups (group A or B) }}
$$

Costs include the design and printing fees for the client reminder, and, in the case of group $B$, the cost of making screening free of charge.

\section{Results}

\section{Baseline characteristics of general health checkup takers}

Table 1 presents the baseline demographic characteristics of the three study groups. No significant differences among the groups were observed by age and gender.

\section{Effectiveness of interventions on the hepatitis virus screening rates}

Figure 4 shows the hepatitis virus screening rates by intervention. While the hepatitis virus screening rate among the control group was $21.2 \%$, group A (who received the nudge-based client reminder) had a $15.9 \%$ higher screening rate at $37.1 \%$. The largest difference was observed between group A and group B, where the hepatitis virus screening rate for group B (who were offered the hepatitis virus screening free of charge) was $49.2 \%$ higher at $86.3 \%$. The effect of the intervention, expressed as the risk ratio to the control group, was 1.75 (95\% CI 1.45-2.12) for group A and 4.08 (95\% CI 3.444.83) for group B.

Also, to examine whether significant differences exist even after adjusting for unobservable heterogeneity per cluster, a regression analysis was performed using generalized linear mixed models. Table 2 shows the estimation results of the generalized linear mixed models. The variables "Group A" and "Group B" represent the effect of each intervention. The parameters were significantly positive for both group A and group B (both $p<0.001$ ), even after adjusting for heterogeneity due to clusters.

Table 1 The baseline characteristics of the participants in the general health checkup

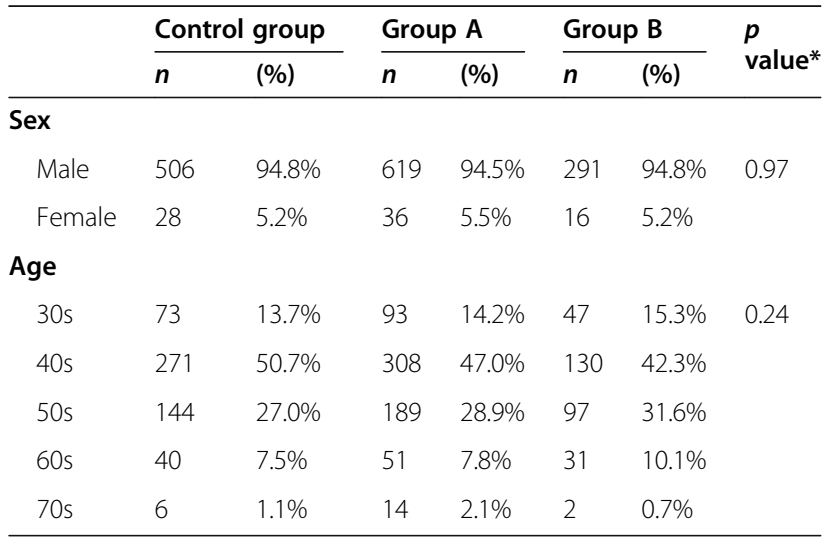

*There was no significant difference among the three groups in sex and age proportion by chi-squared test $n=1496 . \mathrm{SE}$ is standard error, and CI is confidence interval

Cost-effectiveness of each intervention on hepatitis virus screening rates using the ICER calculation

Table 3 shows the cost-effectiveness of each intervention, where a lower ICER value represents greater costeffectiveness. While the ICER for group B is JPY 1168.7, the ICER of group A is JPY 172.5.

\section{$\mathrm{HBV}$ and HCV screening results}

No employee from any of the three groups tested positive for the hepatitis B virus. Additionally, the number of employees from the sample test positive for the hepatitis $\mathrm{C}$ virus was 1 in the control group (0.2\%), 0 in group A $(0 \%)$, and 4 in group B (1.3\%).

\section{Discussion}

To the best of our knowledge, this is the first study to demonstrate the effect of full subsidies and nudge theory on hepatitis screening rates in Japanese worksites. These findings suggest that (i) making screenings free of charge led to the greatest increase in screening uptake, potentially saving many lives and (ii) modifying client reminders using nudge theory could produce a substantial increase in screening uptake at lower costs, making it a viable option in limited-resource settings.

\section{Findings}

Fully subsidized hepatitis virus screening had the highest screening rate of $86.3 \%$, compared to $37.1 \%$ for the nudge-based reminder only and $21.2 \%$ for the control reminder. The effect of the intervention, expressed as the risk ratio to the control reminder, was 4.08 (95\% CI 3.44-4.83) for full subsidy and 1.75 (95\% CI 1.45-2.12) for the nudge-based reminder only. In addition, the parameters were significantly positive for both group A and group B, even after adjusting for heterogeneity due to clusters. Previous studies on cancer screening also showed a rise in screening uptake when fully subsidized [18-20]. However, in our study, the cost of screening was only JPY 612 in the nudge-based client reminder only group, yet screening was $49.2 \%$ lower. This suggests that requiring a co-payment, albeit small, could discourage many people from undergoing screening. Therefore, if feasible, removing co-payments could promote screening in hard-to-reach populations.

Our study also suggests that applying nudge theory to client reminders increased the hepatitis virus screening rates in these worksites. In particular, our results suggest that providing too much information might reduce the 


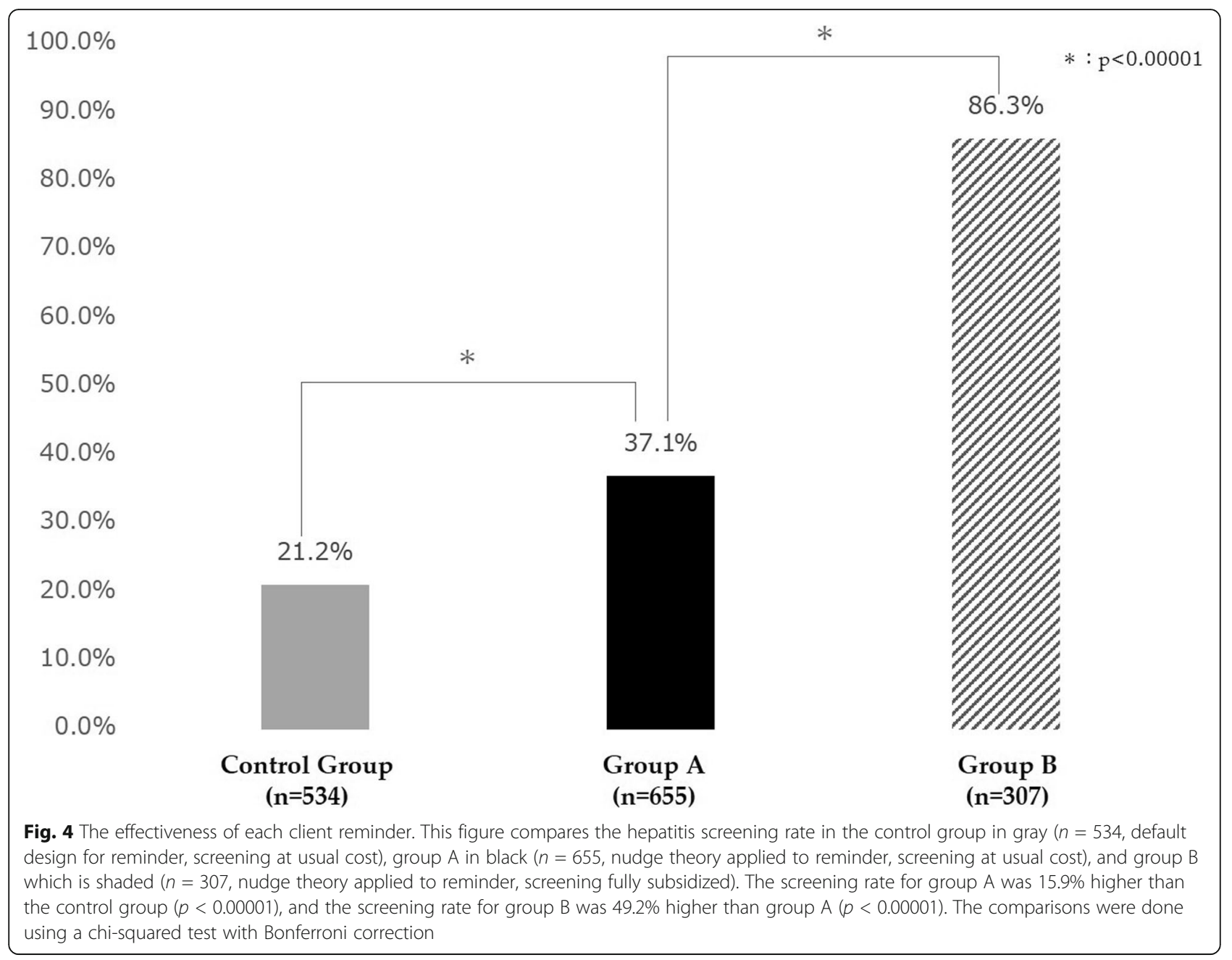

readability of the message, while using nudge-based reminders may increase screening rates in this context. Likewise, a previous study demonstrated that nudgebased client reminders increased colorectal cancer screening rates [14]. To design the nudge-based reminders in this study, we referred to the EAST framework proposed by the UK BIT in their executive report [17], which consists of four principles: (i) "Easy," (ii) "Attractive," (iii) "Social," and (iv) "Timely". This study followed the principles of "Easy" and "Attractive". UK

Table 2 The result of regression using the generalized linear mixed models

\begin{tabular}{lllll}
\hline & $\boldsymbol{\beta}$ & SE & $\mathbf{9 5 \% ~ C l}$ & $\boldsymbol{p}$ value \\
\hline Intercept & -2.241 & 0.437 & $(-3.121,-1.391)$ & $<0.00001$ \\
Group A & 1.109 & 0.312 & $(0.480,1.812)$ & 0.0004 \\
Group B & 3.344 & 0.372 & $(2.595,4.170)$ & $<0.00001$ \\
Female & 1.211 & 0.265 & $(0.696,1.737)$ & $<0.00001$ \\
Age & 0.015 & 0.008 & $(0.000,0.030)$ & 0.0489 \\
\hline
\end{tabular}

BIT recommends, as part of the "Easy" principle, to simplify messages and make them easy to understand. In line with this recommendation, we reduced the number of words on the client reminder. The "Attractive" principle emphasized the importance of drawing attention to important aspects of a message. To this end, the discounted cost of the screening was made salient by striking out the original cost of screening (JPY 2040) and using capital letters for the new cost (JPY 612).

Although making the hepatitis virus screening free produced the highest hepatitis virus screening rates, this led to additional costs. Thus, we performed an incremental cost-effectiveness ratio (ICER) to evaluate the cost-effectiveness of these interventions. The ICER was JPY 1168.7 and JPY 172.5 for the full subsidies and nudge-based reminder only, respectively. Therefore, simply applying nudge theory could significantly increase hepatitis virus screening at lower costs per person, which is critical in low resource settings where offering free screening is not feasible [21, 22]. This finding has implications even at the policy level. In 2011, the Japanese 
Table 3 The cost-effectiveness of the interventions

\begin{tabular}{|c|c|c|c|c|}
\hline & & Control & A & B \\
\hline $\begin{array}{l}\text { Cost for design of } \\
\text { reminder }\end{array}$ & (1) Design fee (JPY) & 0 & $\begin{array}{l}20, \\
000\end{array}$ & 20,000 \\
\hline \multirow[t]{3}{*}{ Cost for all employees } & (2) Number of employees in each group & 534 & 655 & 307 \\
\hline & (3) Printing per person (JPY) & 20 & 20 & 20 \\
\hline & (4) Subtotal cost ((1) $+(2) \times(3))($ JPY) & 10,680 & $\begin{array}{l}33 \\
100\end{array}$ & 26,140 \\
\hline \multirow{3}{*}{$\begin{array}{l}\text { Cost for only screening } \\
\text { takers }\end{array}$} & (5) Number of screening takers & 113 & 243 & 265 \\
\hline & $\begin{array}{l}\text { (6) Subsidization cost for making one screening free of charge (applied only to screening } \\
\text { takers) (JPY) }\end{array}$ & 0 & 0 & 612 \\
\hline & (7) Subtotal cost $((5) \times(6))(J P Y)$ & 0 & 0 & $\begin{array}{l}162, \\
180\end{array}$ \\
\hline Total cost & (8) Total cost $((4)+(7))(J P Y)$ & 10,680 & $\begin{array}{l}33 \\
100\end{array}$ & $\begin{array}{l}188, \\
320\end{array}$ \\
\hline \multirow[t]{3}{*}{ Effectiveness } & (9) Additional cost (JPY) & reference & $\begin{array}{l}22, \\
420\end{array}$ & $\begin{array}{l}177, \\
640\end{array}$ \\
\hline & (10) Number of additional screening takers & reference & 130 & 152 \\
\hline & (11) ICER ((9)/10) (JPY/1 additional screening taker) & reference & 172.5 & $1,168.7$ \\
\hline
\end{tabular}

government decided to offer a free coupon for hepatitis virus screening, spending as much as JPY 3.3 billion yen. However, screening increased only by 446,000 people compared to previous year [23, 24]. If the nudge-based reminder were used, it could have cost substantially less and with better cost-effectiveness.

These results also have implications that could affect social implementation. In our study, the ICER of group A is smaller than that of group B. However, it is possible for this relationship to be reversed if the design costs (more generally speaking, fixed costs) are very large. In fact, for the current sample size, number of screening takers, unit cost of full subsidy, and printing costs, that reversal will happen when the design cost exceeds JPY 914,789. On the other hand, a larger design cost means that the absolute value of the ICER will increase in both groups $\mathrm{A}$ and $\mathrm{B}$, which means that the financial burden on the insurer will be greater than in the present case. In light of this, the intervention should be implemented with as little design or fixed costs as possible, and, in such cases, the nudge-based reminder only will most likely be more cost-effective.

Even though there were approximately 17 million JHIA subscribers in 2018, only 2 million people received hepatitis testing by the end of 2018 [25]. Therefore, we estimated the impact of scaling up the nudge-based client reminder intervention to all 17 million members of JHIA subscribers if screening rates for both HBV and HCV increased by $16 \%$ as shown in our study:

1. The total cost to send nudge-based client reminders will be 341 million yen (20 yen per person for printing and 20,000 yen for designing).
2. Approximately $16,408 \mathrm{HBV}$ carriers and $8204 \mathrm{HCV}$ carriers could be identified (infection rates among the general population for HBV and HCV are estimated at $0.6 \%$ and $0.3 \%$, respectively, according to literature) $[26,27]$.

3. If all the HCV carriers complete their treatment, an estimated 5824 cases of liver cirrhosis could be prevented (approximately $71 \%$ of HCV carriers develop liver cirrhosis [28]).

4. About 1514 liver cancer cases can be prevented (26\% of HCV liver cirrhosis cases typically develop into liver cancer [29]).

\section{Limitations}

This research has several limitations. First, this study was conducted on employees who applied for and attended general health checkups. Because of the nature of these participants, hepatitis virus screening behavior might differ from that of the general population or from employees who did not sign up for the general health checkups. Second, the positive rates for $\operatorname{HCV}(0.2 \%, 0 \%$, and $1.3 \%$ for the control group, group $\mathrm{A}$, and group $\mathrm{B}$, respectively) and the HBV ( $0 \%$ for all three groups) were different from our earlier expectations of $0.6 \%$ for $\mathrm{HBV}$, and $0.3 \%$ for HCV based on previous studies [26]. However, the limited reliability of our measured positive rates due to a small sample size makes it difficult to draw valid comparisons. Third, the demographic data of the sample population is limited to sex and age because the transportation company is not permitted under the Industrial Safety and Health Act to obtain the results of optional tests since companies could identify employees who tested positive and put them at a disadvantage [16]. 
Hence, further studies are needed to address these limitations. Fourth, the analysis only included 13 clusters. However, after adjusting for heterogeneity of each cluster, our study found significant intervention effects. Nevertheless, increasing the number of clusters might allow us for more precise estimations of effects.

\section{Conclusions}

Full subsidies led to the highest increase in hepatitis virus screening rates and could encourage hard-to-reach populations to undergo screening. However, when full subsidies cannot be afforded by health insurance associations in Japan, most of which are facing severe financial deficits, revising the message of the client reminder using nudge theory could be a more cost-effective means for increasing hepatitis virus screening rates.

\section{Abbreviations}

BIT: Behavioural Insights Team; CRC: Colorectal cancer; DAA: Direct-acting antivirals; ICER: Incremental cost-effectiveness ratio; HBV: Hepatitis B virus; HCV: Hepatitis C virus; JHIA: Japan Health Insurance Association; JPY: Japanese Yen; USD: US dollar

\section{Acknowledgments}

We thank Mr. Takao Takeshita, Mr. Shoichiro Habu, and Mr. Tomoaki Tahara from Japan Anti-tuberculosis Association for helping us with collecting and interpreting the data.

\section{Authors' contributions}

J.F. and M.K. conceived and designed the analysis of the obtained data. S.K. performed the statistical analysis. J.F. wrote the first draft of the paper. J.F. contributed to the acquisition of data. J.F. and S.K. contributed to the analysis and interpretation of data. Y.Y. contributed to the simulation of liver cancer mortality reduction. M.K., T.T., S.K., Y.Y., B.S., and L.H. contributed to critical revision of the manuscript for important intellectual content. All authors approved the final version for publication. T.T. supervised the study.

\section{Funding}

This study was funded by Grants-in-Aid for Scientific Research (KAKEN) from the Ministry of Health Labour and Welfare grant number: H26-kansei-ippan001, H29-kansei-ippan-004. The funding sources had no role in the design and conduct of the study; collection, management, analysis, and interpretation of the data; preparation, review, or approval of the manuscript; and decision to submit the manuscript for publication.

\section{Availability of data and materials}

The datasets used and/or analyzed during the current study are available from the corresponding author on reasonable request.

\section{Ethics approval and consent to participate}

This study analyzes the data from a trial program, in which a transportation company conducted the hepatitis prevention activities to address the concerns that the company's employees might have many undiagnosed hepatitis virus infections. To the employees, it was declared on the reminders that the results of this trial might be used for research purposes after anonymization and, for those who did not want to participate, their data could be excluded from the analysis upon their requests. For this analysis, approval was obtained from the Institutional Review Board of the National Center for Global Health and Medicine (No. 2216).

\section{Consent for publication}

Not applicable.

\section{Competing interests}

The authors declare no conflicts of interest. The funders had no role in the design of the study; in the collection, analyses, or interpretation of data; in the writing of the manuscript; or in the decision to publish the results.

\section{Author details}

'Department of Preventive Medicine and Public Health, School of Medicine, Keio University, Shinanomachi, Tokyo 160-8582, Japan. ${ }^{2}$ Hepatitis Information Center, The Research Center for Hepatitis and Immunology, National Center for Global Health and Medicine, Ichikawa, Chiba 272-8516, Japan. ${ }^{3}$ Department of Social and Preventive Epidemiology, School of Public Health, Graduate School of Medicine, Tokyo University, Hongo, Tokyo 113-0033, Japan. ${ }^{4}$ Department of Policy Management, Keio University, Fujisawa, Kanagawa 252-0882, Japan. ${ }^{5}$ Cancerscan, Co., Ltd., Shinagawa, Tokyo 141-0031, Japan. ${ }^{6}$ School of International Health, Graduate School of Medicine, Tokyo University, Hongo, Tokyo 113-0033, Japan.

Received: 8 September 2020 Accepted: 19 January 2021

Published online: 01 February 2021

\section{References}

1. Bray F, Ferlay J, Soerjomataram I, et al. Global cancer statistics 2018: GLOBOCAN estimates of incidence and mortality worldwide for 36 cancers in 185 countries. CA Cancer J Clin. 2018;68:394-424.

2. National Cancer Center, Japan. Cancer Registry and Statistics. https:// ganjoho.jp/reg_stat/statistics/dl/index.html\#mortality. Accessed 11 Feb 2020.

3. Kudo M, Izumi N, Ichida T, et al. Report of the 19th follow-up survey of primary liver cancer in Japan. Hepatol Res. 2016;46:372-90.

4. The Japan Society of Hepatology White Paper on Liver Cancer. http://www. jsh.or.jp/files/uploads/Liver\%20Cancer\%202015.pdf. Accessed 11 Feb 2020.

5. Oza N, Isoda $\mathrm{H}, \mathrm{Ono} \mathrm{T}$, et al. Current activities and future directions of comprehensive hepatitis control measures in Japan: the supportive role of the Hepatitis Information Center in building a solid foundation. Hepatol Res. 2017:47:487-96.

6. Sugiyama A, Fuji T, Nagashima S, et al. Pilot study for hepatitis virus screening among employees as an effective approach to encourage employees who screened positive to receive medical care in Japan. Hepatol Res. 2018;48:291-302.

7. Brouwers MC, De Vito C, Bahirathan L, et al. What implementation interventions increase cancer screening rates? A systematic review. Implement Sci. 2011;6:111.

8. Ueda $Y$, Sobue T, Morimoto A, et al. Evaluation of a free-coupon program for cervical cancer screening among the young: a nationally funded program conducted by a local government in Japan. J Epidemiol. 2015;25: 50-6.

9. Lee JK, Groessl EJ, Ganiats TG, et al. Cost-effectiveness of a mailed educational reminder to increase colorectal cancer screening. BMC Gastroenterol. 2011;11:93.

10. Sun Y, Sarma EA, Moyer A, et al. Promoting mammography screening among Chinese American women using a message-framing intervention. Patient Educ Couns. 2015;98(7):878-83.

11. Ferrer RA, Klein WM, Zajac LE, et al. An affective booster moderates the effect of gain- and loss-framed messages on behavioral intentions for colorectal cancer screening. J Behav Med. 2012;35:452-61.

12. Daniel JO, Jakob DJ. The relative persuasiveness of gain-framed and lossframed messages for encouraging disease detection behaviors: a metaanalytic review. J Commun. 2009;59:296-316.

13. Thaler R, Sunstein C. Nudge. Improving decisions about health, wealth, and happiness. New Haven: Yale University Press; 2008.

14. Misawa D, Fukuyoshi J, Sengoku S. Cancer prevention using machine learning, nudge theory and social impact bond. Int J Environ Res Public Health. 2020;17:790.

15. Basic information on subscribers and medical fees 2015. https://www. kyoukaikenpo.or.jp/g7/cat740/sb7200/sbb7204/h27.

16. Industrial Safety and Health Act. http://www.japaneselawtranslation.go.jp/ law/detail_main?re=\&vm=\&id=1926.

17. EAST. Four simple ways to apply behavioural insights. https://www.bi.team/ wp-content/uploads/2015/07/BIT-Publication-EAST_FA_WEB.pdf. Accessed 25 Feb 2020.

18. Okeke EN, Adepiti CA, Ajenifuja KO. What is the price of prevention? New evidence from a field experiment. J Health Econ. 2012;32(1):207-18. 
19. Skaer TL, Robinson LM, Sclar DA, Harding GH. Financial incentive and the use of mammography among Hispanic migrants to the United States. Health Care Women Int. 1996;17(4):281-91.

20. Kiefe Cl, McKay SV, Halevy A, Brody BA. Is cost a barrier to screening mammography for low-income women receiving Medicare benefits? A randomized trial. Arch Intern Med. 1994;154(11):1217-24.

21. Fukuma S, Ikenoue T, Sasaki S, Saigusa Y, Misumi T, Saito Y, Yamada Y, Goto $\mathrm{R}$, Taguri M. Nudging patients with chronic kidney disease at screening to visit physicians: a protocol of a pragmatic randomized controlled trial. Contemp Clin Trials Commun. 2019;16:100429.

22. Ishikawa Y, Hirai K, Saito H, et al. Cost-effectiveness of a tailored intervention designed to increase breast cancer screening among a non-adherent population: a randomized controlled trial. BMC Public Health. 2012;12:760.

23. 2011 Government Budget (Hepatitis Countermeasures). https://www.mhlw. go.jp/stf/shingi/2r98520000012eqm-att/2r98520000012f3c.pdf. Accessed 5 Dec 2020

24. Health and hygiene (hepatitis virus countermeasures). https://www. gyoukaku.go.jp/review/aki/r01tokyo/img/g11.pdf. Accessed 5 Dec 2020

25. Ji-gyou Houkoku-sho(JHIA Business Report (2008-2018)). Available at https:// www.kyoukaikenpo.or.jp/g7/cat710/sb7060/1778-23530/. Accessed on 25 July 2020.

26. The results of hepatitis virus examination by Health Promotion Act in 2016 https:/www.mhlw.go.jp/bunya/kenkou/kekkaku-kansenshou09/pdf/kensa-19.pdf.

27. Korenaga M, Ooe C, Kamimura K, et al. Tailored message interventions using social marketing approach increase the number of participants in viral hepatitis screening for Japanese workers -multicenter trial of 880,000 general checkup applicants. Hepatology. 2019;70(Suppl 1):460A.

28. Seeff LB. Natural history of chronic hepatitis C. Hepatology. 2002;36(5 Suppl 1):S35-46.

29. Ikeda K, Saitoh S, Suzuki Y, et al. Disease progression and hepatocellular carcinogenesis in patients with chronic viral hepatitis: a prospective observation of 2215 patients. J Hepatol. 1998;28:930-8.

\section{Publisher's Note}

Springer Nature remains neutral with regard to jurisdictional claims in published maps and institutional affiliations.

Ready to submit your research? Choose BMC and benefit from:

- fast, convenient online submission

- thorough peer review by experienced researchers in your field

- rapid publication on acceptance

- support for research data, including large and complex data types

- gold Open Access which fosters wider collaboration and increased citations

- maximum visibility for your research: over $100 \mathrm{M}$ website views per year

At $\mathrm{BMC}$, research is always in progress.

Learn more biomedcentral.com/submissions 